\title{
VICTORIA LOWER GLACIER AND ROSS SEA GLACIATION, DRY VALLEYS AREA, SOUTH VICTORIA LAND, ANTARCTICA
}

\author{
By T.J.H. CHINN
}

(Soil Conservation Group, Ministry of Works and Development,

Box 1479, Christchurch, New Zealand)

ABSTRACT. Victoria Lower Glacier is a complex structure of ice from two distinct sources (Schultz Glacier to the north and a local névé of Victoria Lower Glacier) that join at a broad median shear zone. Evidence from the margins suggest that both are currently retreating. Algae in a block of frozen stratified sediment from within the ice of the terminal margin has a radiocarbon age of $20200 \pm 2400$ year BP (NZ 6531 A), indicating that the glacier has advanced since that time. Superposition of ice levels of Ross Sea I glaciation on a radio echo-sounding profile of bedrock beneath the glacier indicates that it is unlikely that Ross Sea I ice entered the valley. The radiocarbon date supports this finding.

\section{INTRODUCTION}

Dry-based glaciers of the Dry Valleys area descend into major valleys cut by very old (late Tertiary) glaciations (Selby and Wilson, 1971; Mayewski, 1975; Denton and others, 1984) and are frequently encircled at the snouts by arcuate moraines attributed to Alpine glaciation episodes I, II, and III (Calkin and others, 1970). These moraines have been correlated with valley-floor deposits in Taylor Valley where the oldest of these events is dated between 2.2 and 3.6 Ma BP (Denton and others, 1970; Denton, 1971). There is little evidence of recent fluctuations of these glaciers.

The last major glacial event (Ross Sea I glaciation) in the Dry Valleys area was an inland incursion of an expanded and grounded Ross Ice Shelf into the seaward ends of the main valleys which reached a maximum between 17000 and 21200 radiocarbon years BP (Denton and others, 1970). Ice levels of this advance reached to about $700 \mathrm{~m}$ above present sea-level seaward of Victoria Valley. Ross Sea I ice had effectively retreated from the Dry Valleys by about 8000 radiocarbon years BP (Hendy and others, 1979; Stuiver and others, 1981), leaving the Ross drift deposits which are commonly ice-cored.

It is possible that ice of the Ross Sea I event entered Victoria Valley. From airborne radio echo-sounding measurements, Calkin (1974) gave an elevation of about $600 \mathrm{~m}$ for the subglacial threshold across lower Victoria Valley. This could have permitted a tongue of ice, up to $100 \mathrm{~m}$ thick, to enter lower Victoria Valley during the last Ross maximum. Deposits of three undated advances of Victoria Lower Glacier (from youngest to oldest), the Packard, Vida, and Bull drifts, mapped by Bull and others (1962) and Calkin (1971), show that ice extended at least $10 \mathrm{~km}$ further inland past the present glacier terminus. Borns (1982) suggested that ice reached $15 \mathrm{~km}$ farther inland. It is tempting to assign the shorter of these advances (the Packard drift episode) to the Ross Sea I event. In a re-examination of lower Victoria Valley, Borns (1978) concluded that it was possible that ice of the Ross Sea glaciations invaded the valley several times.

Victoria Lower Glacier, at lat. $77^{\circ} 21^{\prime} \mathrm{S}$., is a $3.5 \mathrm{~km}$ wide ice tongue flowing south-westward and inland into Victoria Valley from the coastal Wilson Piedmont Glacier (Fig. 1). The tongue is typical of the glaciers of the area which carry minimal surficial debris and terminate at icecliffed margins (Chinn, 1980, 1981). From a névé area at

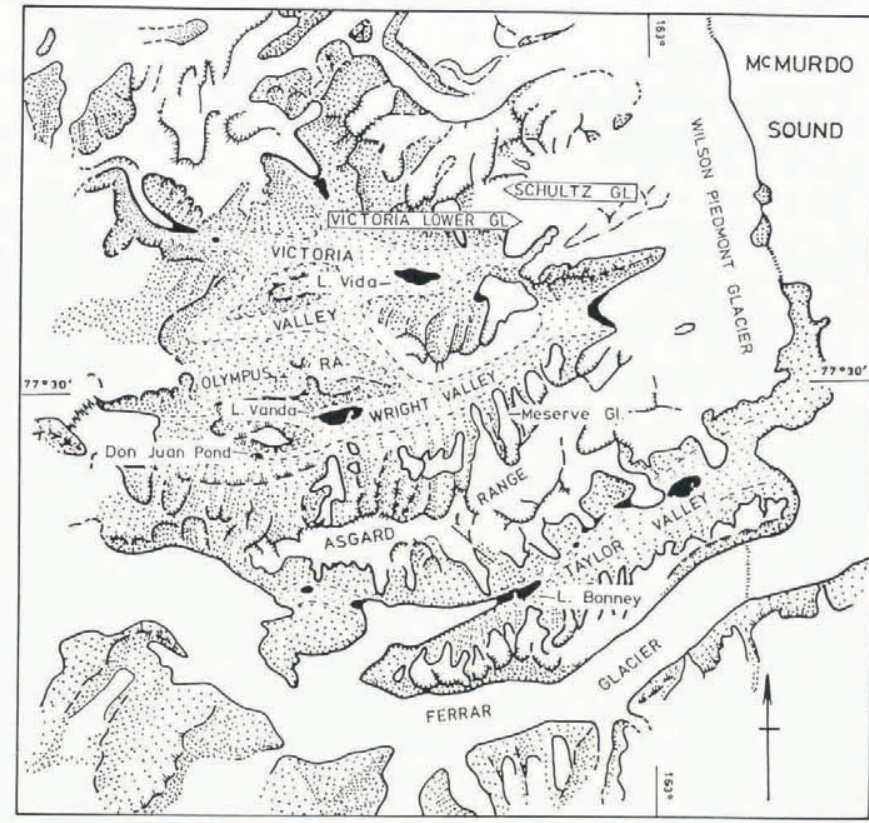

DRY VALLEYS REGION, ANTARCTICA

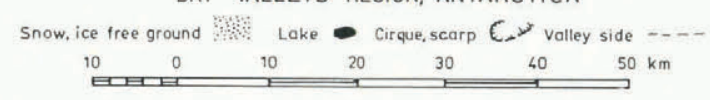

Fig. 1. Victoria Lower Glacier: location map.

$700 \mathrm{~m}$ altitude, the glacier tongue extends for $5 \mathrm{~km}$ to terminate at an elevation of $400 \mathrm{~m}$. Three distinct areas of different ice textures ("A", "B", and "C" of Figure 2) are apparent on U.S. Navy aerial photograph TMA 2298-0037. These phenomena were investigated during the 1981-83 austral summer when a study was made of the morphology and structure of the glacier and the details of this work are presented here.

\section{GLACIOLOGICAL OBSERVATIONS}

\section{Surface features}

Although Victoria Lower Glacier appears to be an inland extension of a tongue of the coastal Wilson Piedmont Glacier, the true extent of the glacier and sources of ice feeding the tongue may be delineated by constructing flow lines on a contour map (lines drawn normal to mapped contours of a glacier surface closely follow ice-flow lines and may be used to trace flow paths). Flow lines constructed for Victoria Lower Glacier and part of Wilson Piedmont Glacier (Fig. 3) provide an approximate position for the ice divide between these two glaciers. Over half of the ice of Victoria Lower Glacier is supplied by Schultz Glacier entering from the north side of the valley, while the remainder of the glacier is fed by a low nevvé area to the south side of the valley. There is apparently no supply from Wilson Piedmont Glacier. 


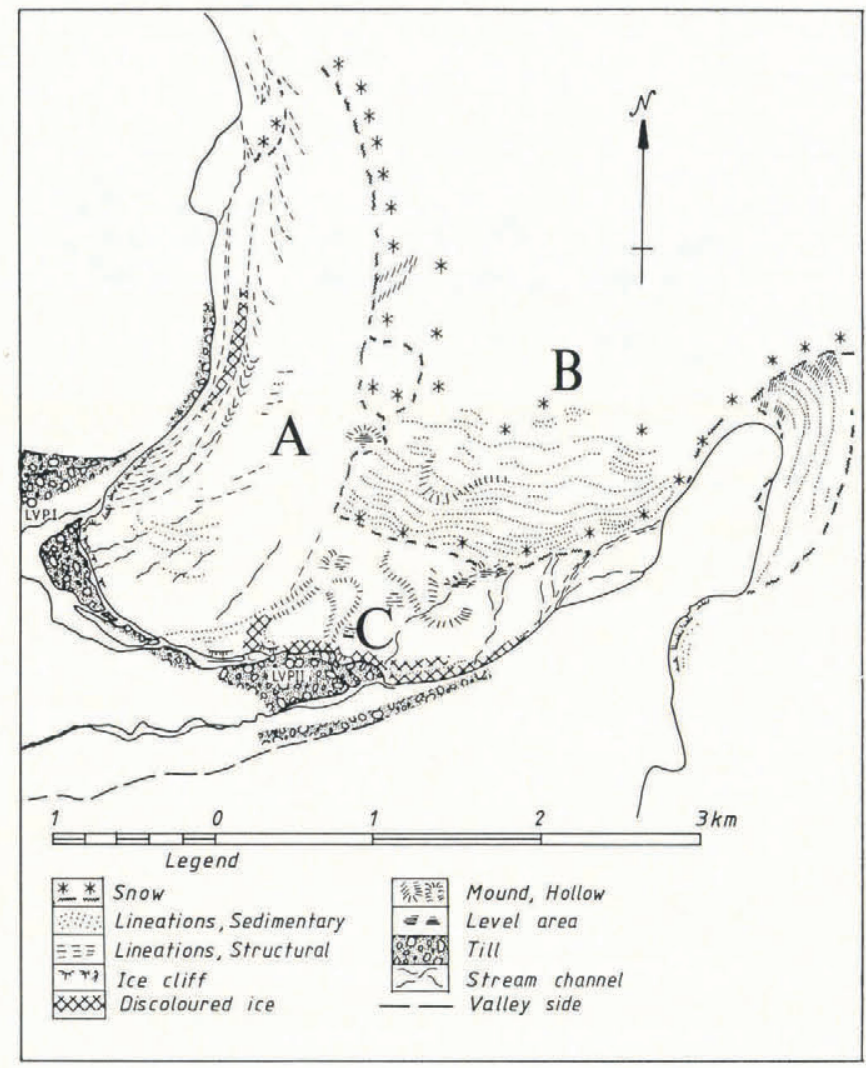

Fig. 2. Victoria Lower Glacier: surface features. " $A$ ", "B", " $C$ " designate three areas of different surface textures. LVPI, LVPII indicate photo-theodolite stations.

Surface ice of Schultz Glacier (area "A"; Fig. 2) is debris-free and almost completely clear of snow. The level of this ice is slightly above that of névé area "B", which may increase exposure to the wind, thus accounting for the absence of snow accumulation. Area "A" terminates at ice cliffs reaching $34 \mathrm{~m}$ high in an embayment in the western corner. Elsewhere, the cliffs become progressively lower and more subdued, especially towards the ice-ramp margin at the contact between areas " $\mathrm{A}$ " and " $\mathrm{C}$ ".

Névé area "B" (Fig. 2) is a relatively small accumulation zone of discoloured snow, well situated to collect snow and sand carried by westerly winds (barchan sand dunes occur only a few kilometres west of the glacier). The surface texture of the névé area is a result of aeolian sand being trapped by the rough snow surface, and the banded structure of the lower margin of the area is a sedimentary structure of alternating sandy and snow layers.

Accumulation area "B" discharges discoloured ice into ablation area "C", where the lower surface albedo encourages melt and refreeze processes. Almost all of the near-surface glacial structures of area " $\mathrm{C}$ " have been obliterated by this activity. The tongue has an undulating topography with at least two large depressions, which are in part infilled by refrozen melt water. This section of the glacier terminates in steep ice ramps rather than ice cliffs.

\section{Sub-surface features}

The internal ice structure of the three areas was studied by measuring attitudes of the various beds and foliae using a compass clinometer. The most common structural indicator was discoloured foliation but clean ice bands and elongated bubble trains were also evident. Foliation was often quite subtle inward of the glacier margins, and frequently obscured by snow or "water ice", i.e. ice superimposed by refreezing of melt water. Dips were measured at small sections cut into the ice with an ice-axe. Subtle foliation was frequently more easily discerned if cut sections were left for a day or more for the "streak" of fractures and chips to sublime. Strike directions were determined using a magnetic compass, which performed satisfactorily, though sluggishly, in this region of high magnetic dip.

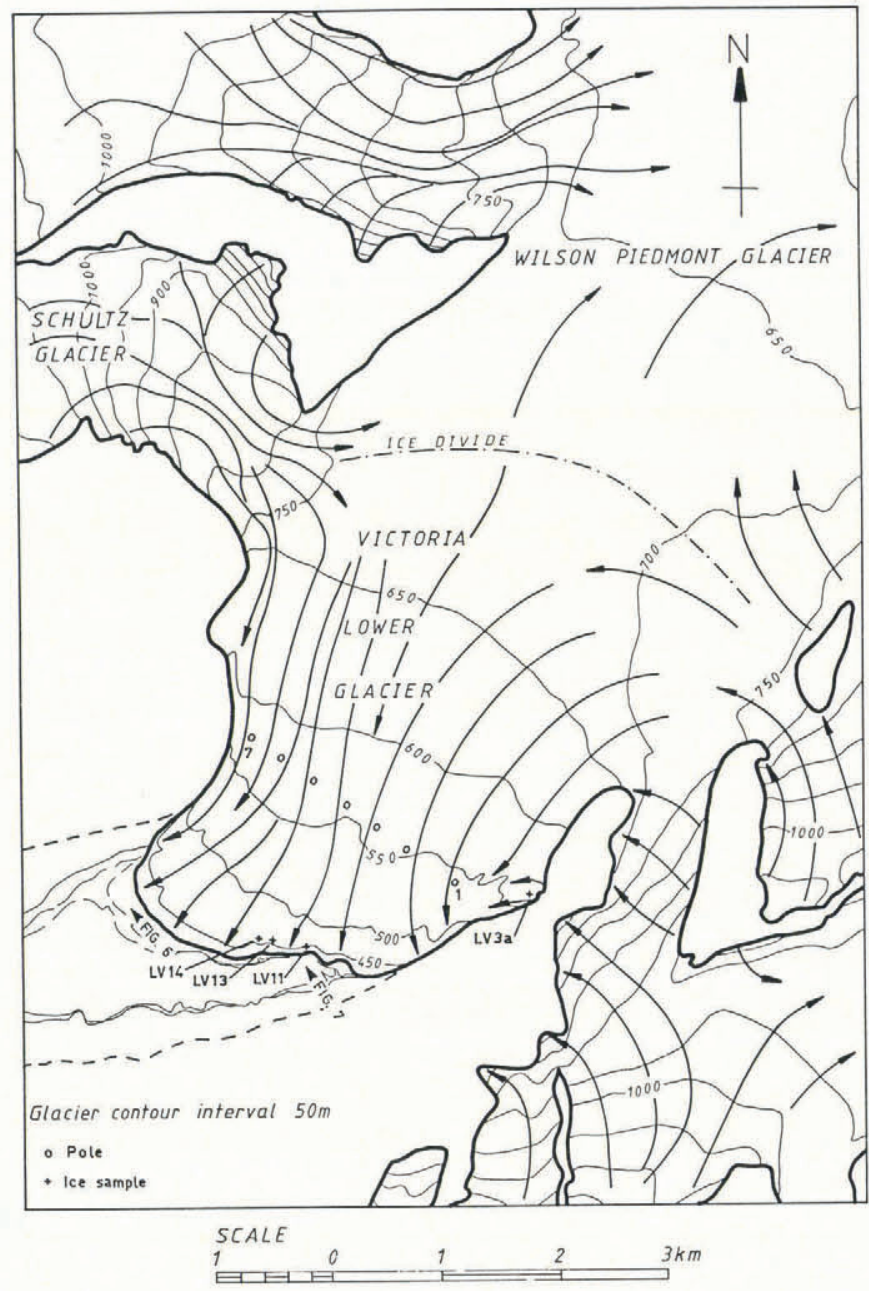

Fig. 3. Victoria Lower Glacier and adjacent glaciers: contours and flow lines showing directions of ice flow. Locations of ice samples LV3a, LV11, LV13, LV14 are shown, together with approximate positions of poles installed by Calkin (unpublished) over summer 1961-62, and locations of Figures 6 and 7.

\section{RESULTS}

Schultz Glacier ice, area " $A$ "

Schultz Glacier ice (Fig. 4) is broadly synclinal in structure, with a wide, steeply dipping deformation zone parallel to the northern margin. Dips in this zone become less steep towards the snout, where the structure is generally inward dipping. A wide intense deformation zone separates Schultz Glacier ice from Victoria Lower Glacier ice. Here, elongated discoloured structures containing stretched rodshaped bubbles showed obscure vertical dips. The obscure bedding and patchy cover of snow and water ice make the extent of this structure uncertain. At the glacier front, foliation of basal Schultz Glacier ice curls upwards quite steeply to up-glacier dips of $30^{\circ}$. A set of ogive-like structures adjacent to the northern shear zone forms a single synclinal fold (or monoclinal fold as the south limb fades into unfoliated ice), with a steep up-stream plunge of $54^{\circ}$ (Fig. 5).

Glaciers of the Dry Valleys area terminate at perpendicular ice cliffs, domed-ramp or sloping-ramp margins, and the inflection between the glacier margin and adjacent ground is normally infilled with a wedge of winddrifted snow interbedded with refrozen melt water (Chinn, 1985). In this respect, part of the terminus of Victoria Lower Glacier is unusual. The cliffed frontal margin of ice body "A" lacks the usual snow wedge; instead, the position is occupied by a trough (Fig. 6). This elongated depression, up to $16 \mathrm{~m}$ wide and $3 \mathrm{~m}$ deep, separates the glacier from a sandy surface which slopes outward at $3^{\circ}$. This sand deposit 


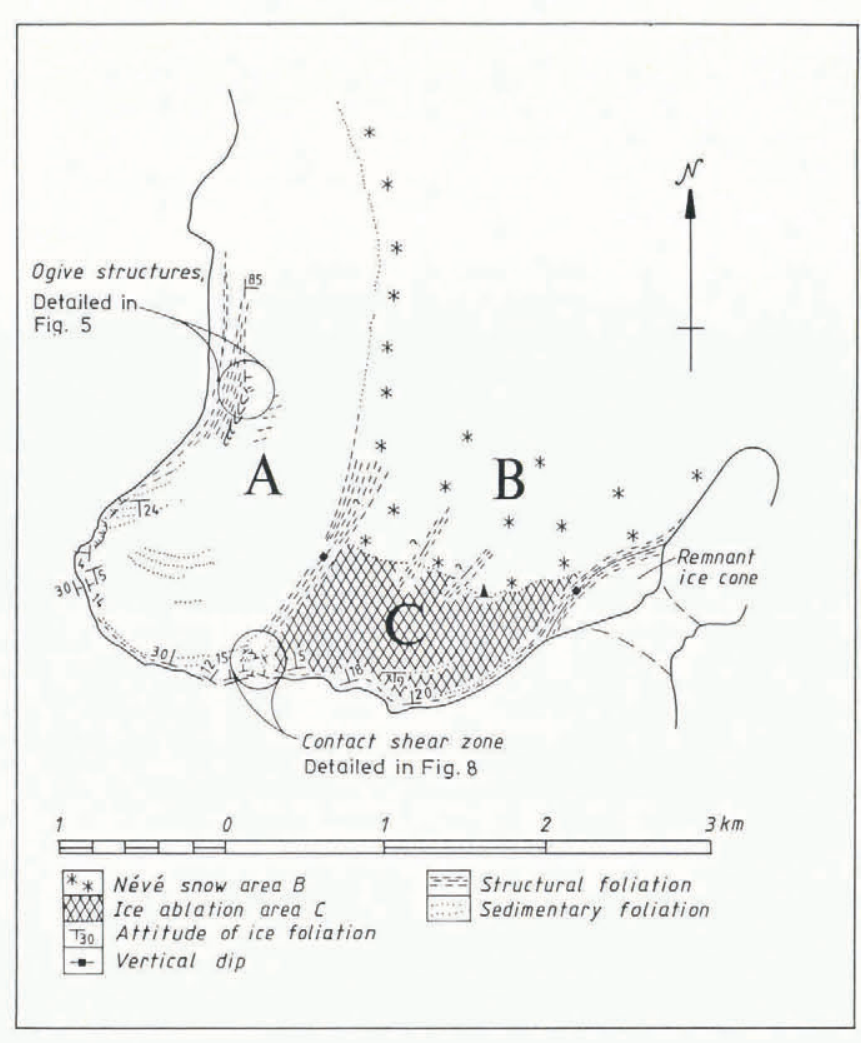

Fig. 4. Victoria Lower Glacier: structural map.

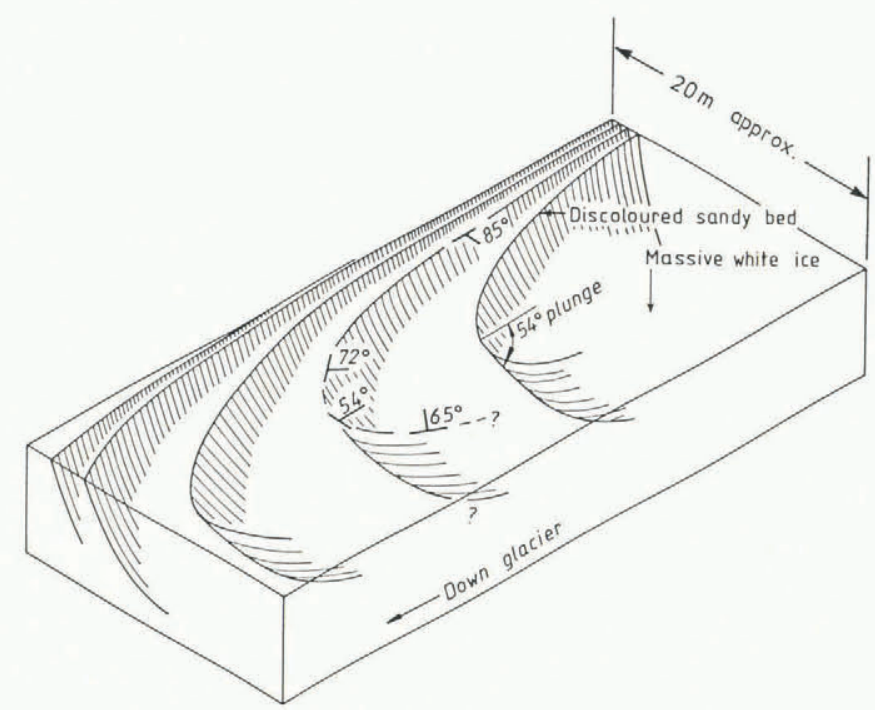

Fig. 5. Single fold at the margin of northern shear zone, Schultz Glacier ice, area "A". Detail of part of Figure 4.

thinly veneers glacial ice whose structural attitude is in accordance with that of the glacier front. The feature is either an extension of the glacier itself or, if disconnected, a type of ice-cored moraine.

\section{Ablation area " $C$ "}

The surface of the ablation zone of Victoria Lower Glacier (area "C") is predominantly an aggradation of melted and refrozen ice and snow showing little of the internal ice structure on its undulating surface. The undulations are believed to indicate shallow ice over uneven bedrock. Zones of linear foliation, extending down-glacier parallel to flow, occur in the upper middle of this area and intensify towards the southern margin. These foliations are interpreted as shear structures.

The deformation zone at the southern margin of area " $\mathrm{C}$ " circumvents the toe of a cone of white ice lying directly below the snout of a small glacier (Fig. 4) and separates the ice cone from the main body of area "C". The cone is remnant, severed by recent ablation from this small tributary glacier. $50-100 \mathrm{~m}$ of bare ground between the ice cone and the present small glacier front is veneered by fresh debris, with gravel and sand lying loosely on larger boulders. The cliffed snout of the receding glacier front is low (less than $20 \mathrm{~m}$ ), has little, if any, surrounding ice apron, and overlies a thin bed of discoloured basal ice only $10-20 \mathrm{~cm}$ thick. It has been demonstrated (Chinn and Cumming, 1983; Chinn, 1985) that, when ice cliffs at the terminus of Dry Valleys glaciers are below $20 \mathrm{~m}$ in height and have a small apron of less than one-fifth of the total cliff height, the glacier is receding.

Ice body " $\mathrm{C}$ " has at its terminus an abnormally thick zone of discoloured basal ice. Alternating bands of debrisrich, grey-brown ice, and white ice form a basal ice bed, up to $10 \mathrm{~m}$ thick at the glacier front (Fig. 7). Bedding is irregular and lensoid in places, with an up-glacier dip. At the contact with the shear zone separating this zone from Schultz Glacier ice "A" (Fig. 8a), the foliation appears to be folded downward as drag folds (Fig. 8b) rather than upward into the shear zone, as might be expected at an ice margin.

\section{Algal sand block inclusions}

The banded and discoloured ice at the terminus of area " $\mathrm{Cl}$ contains, in positions up to $10 \mathrm{~m}$ above the glacier base, irregular-shaped blocks of well-sorted, laminated sand that range from $0.5 \mathrm{~m}$ to $4 \mathrm{~m}$ across. The blocks are not deformed and are similar to deltaic blocks described by Harris and Bothamley (1984) from a temperate glacier in southern Norway. The uniformity of the sediments and thickness of the blocks, together with a high concentration of salts, suggest that they are derived from a former lake or pond, rather than a stream bed. One of these blocks, located in Fig. 8a, contained beds of algae which provided sufficient material for a radiocarbon date (Fig. 9). This sample gave a radiocarbon age of $20200 \pm 2400$ year BP (NZ 6531 A). At the time that the pond or lake existed, the glacier terminus must have been well behind its present position as the block has been over-ridden, entrained into the ice, and transported to the glacier terminus.

\section{Margin position}

Victoria Lower Glacier is included within a phototheodolite survey programme (Chinn and Cumming, 1983; Chinn, 1985) recording changes in the margins of selected Dry Valleys glaciers by comparing photographs repeated over an interval of a number of years. Photographs taken in 1973 from bench mark LVPI (Fig. 2) and repeated in 1979 show that from this site the change over the interval was of minor recession. The results from bench mark LVPII, although also showing a small recession, are inconclusive as the foreground in the view from LVPII could not be made to align, suggesting that the moraine ridge supporting the bench mark is ice-cored and connected to, and moving with, the glacier.

\section{Moraines}

A number of prominent ridges of moraine occur against and up to $100 \mathrm{~m}$ from the terminus of ice body " $\mathrm{C}$ ". A few exposed sections showed that these ridges are icecored over at least part of their lengths, while movement of the photo-theodolite bench mark LVPII (Fig. 2), which is located on one of these ridges, suggests the existence of extensive ice cores which are undergoing some deformation caused by movement of the glacier. Some of the ridges are parallel to the present glacier margin, while others appear to curve under the glacier, which is consistent with having been over-ridden.

\section{Chemical analyses}

Chemical analyses were made of ice samples from the different ice bodies and the results are listed in Table I together with the results of similar analyses, given for comparison, which were made at Meserve Glacier in the adjacent Wright Valley (Holdsworth and Bull, 1970). The chemistry of Victoria Lower Glacier is also compared in Figure 10 with waters from other areas in the Dry Valleys given in Torii and others (1981). 


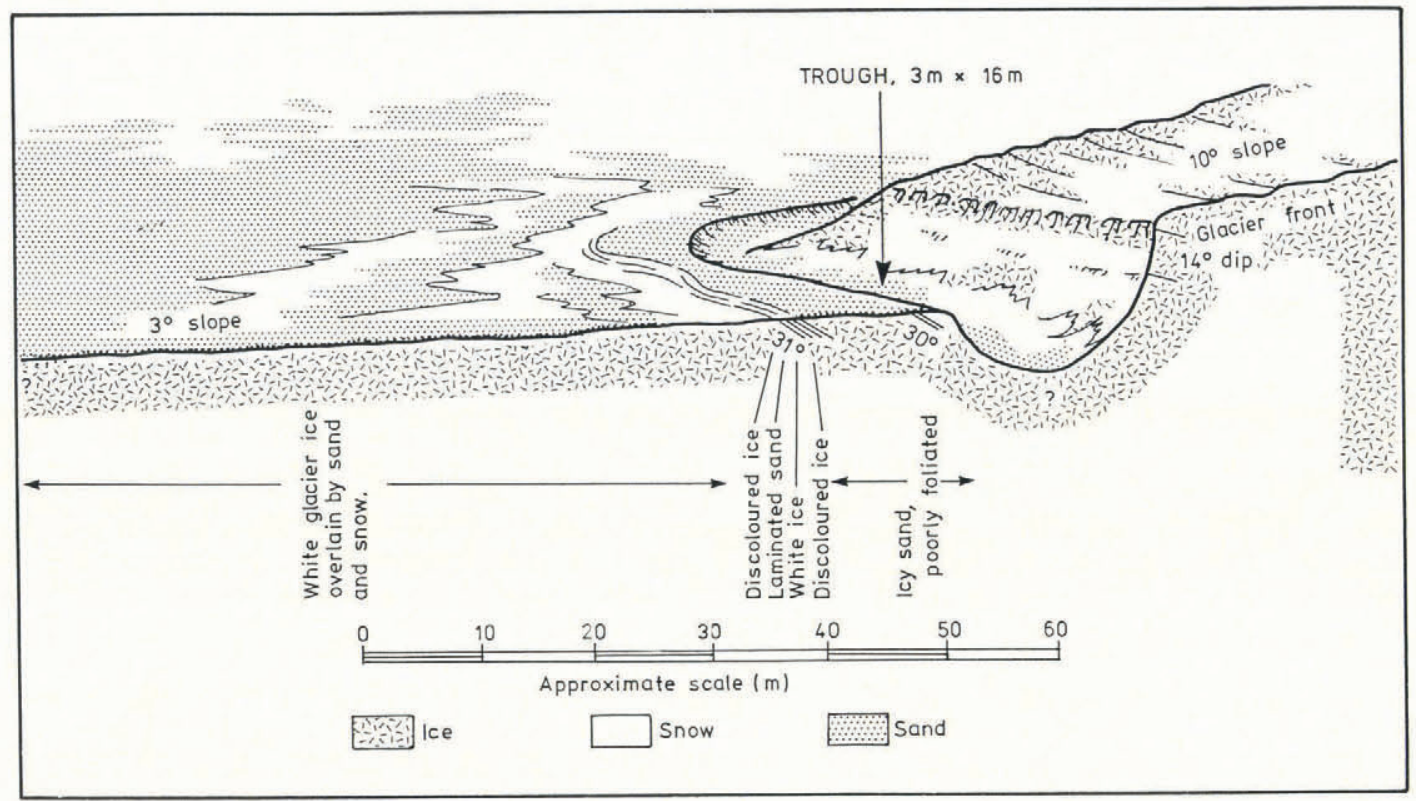

Fig. 6. Sectional sketch of trough and ice-foliae attitudes at terminus of ice body " $A$ ".

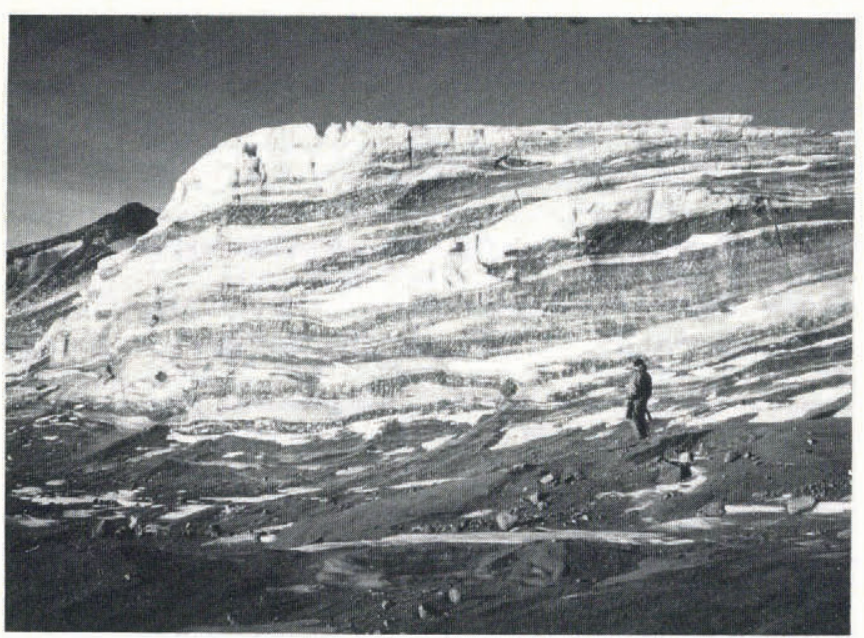

Fig. 7. Thick beds of discoloured ice at the terminus of ice body " $C$ ". Ice-cliff height approximately $6 \mathrm{~m}$; figure is at the site of the radiocarbon sample.

TABLE I. CHEMICAL ANALYSES OF ICE SAMPLES FROM LOCATIONS SHOWN IN FIGURE 3, WITH RESULTS OF A SIMILAR ANALYSIS FOR COMPARISON, MADE AT MESERVE GLACIER IN THE ADJACENT WRIGHT VALLEY (HOLDSWORTH AND BULL, 1970)

Sample and concentration

Ion

LV3a LV13 LV14 LVI1

$\mathrm{Na}^{+}$

$\mathrm{K}^{+} \quad 1.4$

$\mathrm{Ca}^{++} \quad 2.4$

$\mathrm{Mg}^{++} \quad 0.62$

\section{7}

1.2

1.8

0.39

5.4

5.1

\begin{abstract}
4.7
\end{abstract}
1.3

1.8

0.38

4.2

6.0

4.0

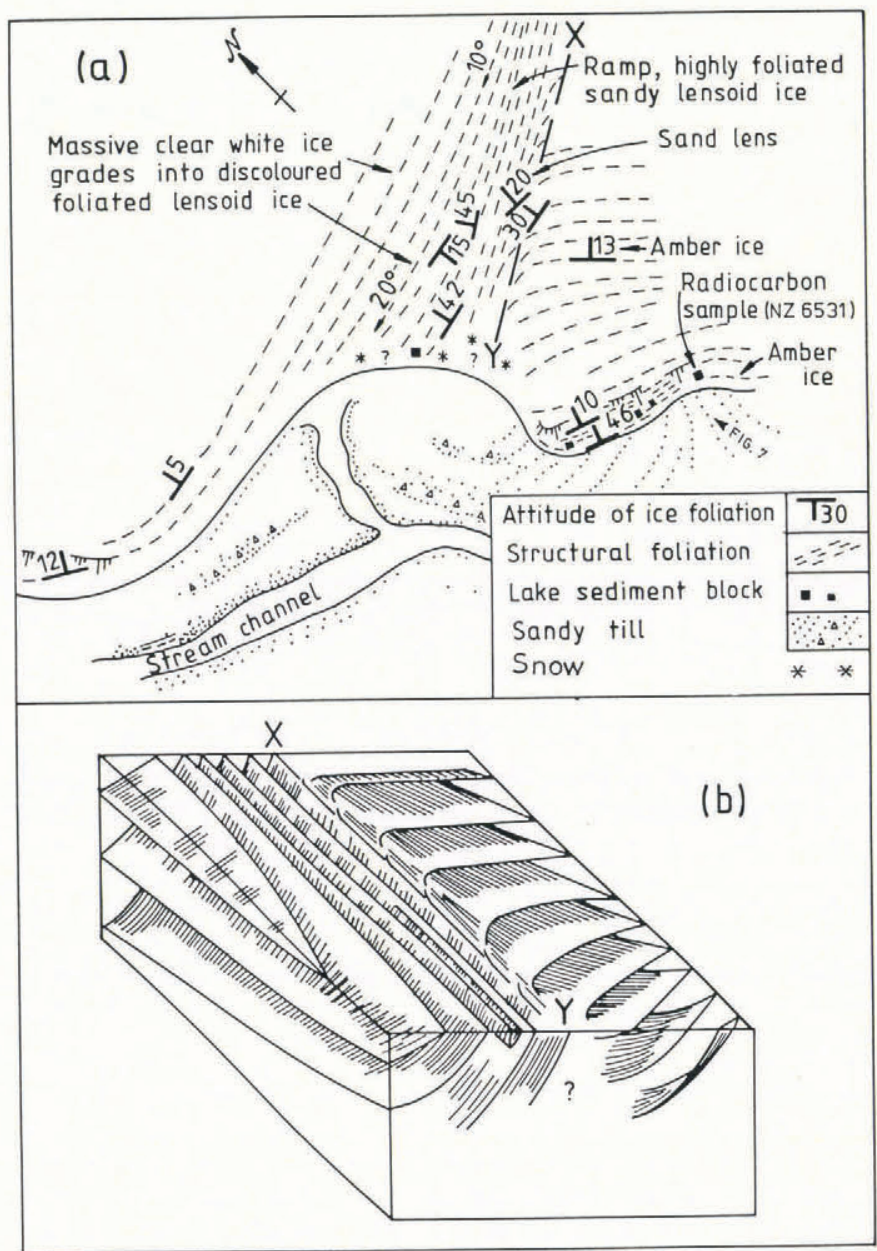

Fig. 8. Ice structures of the shear zone between areas " $A$ " and " $C$ " at the terminal margin. Detail of part of Figure 4: (a) sketch map of glacier margin, width of sketch approximately $300 \mathrm{~m} ;$ (b) interpretative diagram of structure along $\mathrm{X}-\mathrm{Y}$. 


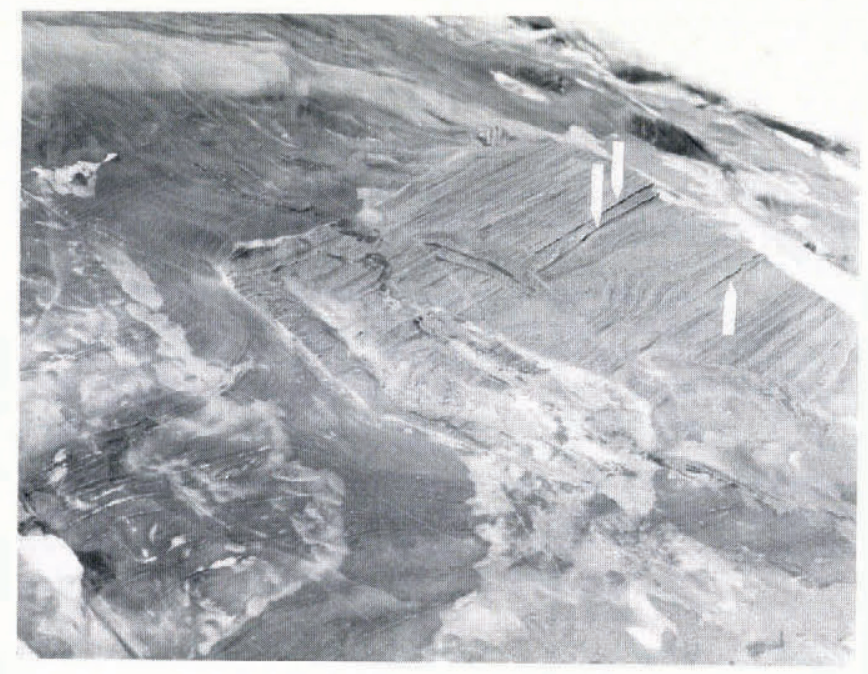

Fig. 9. Block of laminated sediments containing radiocarbon sample embedded in the front of ice body " $C$ ". Block is approximately $2 \mathrm{~m}$ in diameter; beds of algae indicated by arrows.

TABLE II. ABLATION AND MOVEMENT MEASURED BY CALKIN (UNPUBLISHED) DURING THE 1961-62 SUMMER

(Locations of poles shown on Figure 3)$$
\text { Pole }
$$$$
\text { Ablation }
$$$$
\left(\mathrm{mm} \text { water } \mathrm{d}^{-1}\right. \text { ) }
$$

0.3
0.3
2.2
1.6
2.2
2.5
1.9

\section{Movement} $\mathrm{mm} \mathrm{d}^{-1}$

0 , no movement recorded

-
-
3.4
-
-
6.0

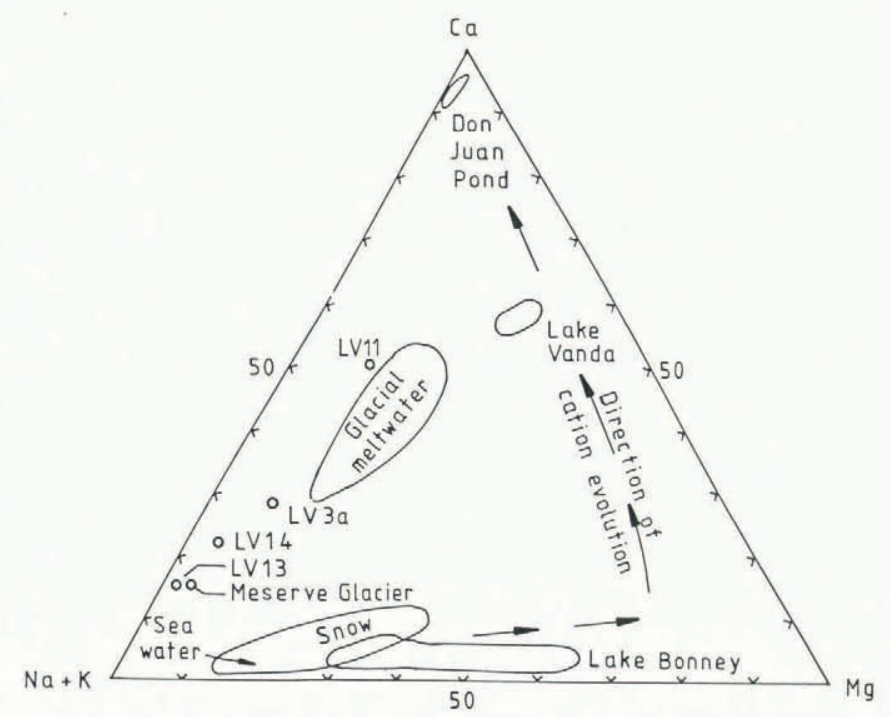

Fig. 10. Chemical composition of ice samples from Victoria Lower Glacier compared with different types of waters in the Dry Valleys area (after Torii and others, 1981).

\section{Ablation and movement}

Over the 1961-62 summer season, Calkin installed a line of seven poles across the glacier snout (Calkin, unpublished) at locations shown on Figure 3. The results of Calkin's ablation and movement measurements are given in Table II. Ablation was highest on the white ice of area "A" and lowest over the discoloured ice of upper area " $\mathrm{C}$ ", while movement was greatest on area "A".

\section{DISCUSSION}

\section{Structure}

Victoria Lower Glacier was found to comprise ice derived from two separate sources joined at a wide zone of intense foliation, approximately bisecting the tongue (Fig. 4). Together, these two ice bodies form three visually distinct ice areas comprising the glacier tongue:

"A" clean Schultz Glacier ice.

"B" dirty banded firn and snow of Victoria Lower Glacier névé.

"C" Victoria Lower Glacier ice, largely covered with discoloured water ice from refrozen melt caused by sand caught in the névé.

At the lateral margins of a structurally simple glacier, both sedimentary and structural foliation tend to parallel the margins, and to extend across the glacier tongue in a synform parallel to the ice front of the terminus. The tongue of Victoria Lower Glacier broadly follows this trend at its margins and over the area of sedimentary foliation in area "B". But large areas of the tongue show strong longitudinal foliation parallel to the direction of flow. These structures are interpreted as shear zones generated where the faster-flowing Schultz Glacier ice deforms against the slower-moving shallow ice of area " $\mathrm{C}$ ". The surface undulations of area " $\mathrm{C}$ " suggest a reflection of the underlying topography through a shallow ice cover. The three flow measurements made by Calkin (unpublished) over an 83 day period support this suggestion (Table II). Surface gradients of both areas "A" and "C" are similar yet flow in Schultz Glacier ice was measured at $6 \mathrm{~mm} \mathrm{~d}^{-1}$, while no movement was detected near the margin of area " $C$ ". Shear zones continue intermittently from the central zone across area " $\mathrm{C}$ " to intensify at the southern margin (Fig. 4) where strong deformation occurs where ice "B" and "C" flows around the "stagnant" ice cone.

The ogive-like structures located in Figure 4, and detailed in Figure 5, may be explained as a local area of drag deformation between areas of ice of different velocities. The sharply defined and deformed junction near the snout between ice bodies " $\mathrm{A}$ " and " $\mathrm{C}$ " suggests a considerable difference in respective ice velocities, leading to a structure compatible with both drag and compression (Fig. $8 \mathrm{~b})$. The very thick beds of discoloured and sediment-rich ice at the terminus of area " $\mathrm{C}$ ", which comprise almost the entire glacier terminus, have not been observed developed to such an extent on other glaciers of the Dry Valleys area. Normally, this basal "amber ice" is approximately $1 \mathrm{~m}$ in thickness (Holdsworth and Bull, 1970) but has been observed to vary from as little as $20 \mathrm{~cm}$ to over $3 \mathrm{~m}$. The very thick Victoria Lower Glacier beds (Fig. 7) may result from unusually high compressive flow thickening the basal ice layers, while the upper ice has been lost to ablation.

\section{Glacier equilibrium}

$A$ number of features at the margin do indicate that ice is at present receding, although the internal structure of the Victoria Lower Glacier system does not provide information on the present equilibrium of the glacier. The distal ice-cored moraines surrounding the terminus indicate a past position of the glacier, although this could be quite old. Ice-cored Ross Sea drift has survived the entire Holocene at many locations in the Dry Valleys. The depression below the frontal ice cliffs is presumably an ablation feature formed by accelerated ablation at the foot of the ice cliff (Chinn, in press). Advancing ice would almost certainly destroy this feature. A comparison of photographs taken from point LVPI also confirms a minor recession, while a similar minor recession observed from 
LVPII should be dismissed, as the bench mark is suspected to be unstable. The most positive evidence of local recession is demonstrated by the stranded ice cone (Fig. 4) with its tributary glacier source withdrawn nearly $0.5 \mathrm{~km}$ beyond the apex of the detached ice body. The only evidence for an advancing margin was from the measured height of $34 \mathrm{~m}$ for the ice cliff at the north-western corner of the glacier. The suggestion that this part of the glacier may be advancing is based on cliff height alone (Chinn, 1985).

Significance of the algal-sand inclusions and the Ross Sea I glaciation

Results of chemical analysis of the ice samples taken from Victoria Lower Glacier are compared in Figure 10 with the chemical compositions from other locations in the Dry Valleys area measured by Torii and others (1981). The cation ratios of these samples lie between those of Dry Valleys glacier melt water and sea-water, and are chemically similar to basal amber ice from Meserve Glacier (Table I) Analysis of water melted from the sediment block found embedded in the glacier (sample LVII) shows a chemical composition with cation ratios similar to that of glacier melt water, but at high concentrations similar to those found in lakes of the Dry Valleys area. This indicates that the salts have been highly concentrated over a relatively short geological period of time and have not undergone any significant cation evolution from evaporation and other processes associated with a frigid environment, as described by Torii and others (1981). Evolutionary changes in cation ratios require relatively long periods of time (of tens of thousands of years), while high concentrations of salts may be achieved by ablation in a matter of hundreds of years. The trend in cation evolution is a compositional change with time (Fig. 10) from the cation ratios of glacier melt water to sea-water, then towards higher $\mathrm{Mg}^{++}$ratios, as in lake waters (Lake Bonney, Taylor Valley), and finally, after many tens of thousands of years, to evolve to a $\mathrm{Ca}^{++}$base, such as occurs in Don Juan Pond (Torii and others, 1981).

Although the ice level of the last Ross Sea glaciation event at approximately 20200 year BP was up to $100 \mathrm{~m}$ above the rock threshold at the mouth of Victoria Valley, and could have supplied ice to the Victoria Lower Valley, it may not have done so. The gradient of the glacier surface may have caused the ice margin to terminate below and seaward of the threshold (Fig. 11). At the same time, an expanded Ross Ice Shelf would have increased the fetch

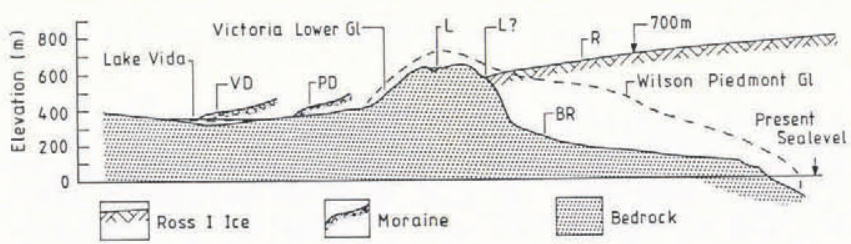

Fig. 11. Profile of Victoria Lower Glacier at 20200 year BP. R, level of Ross Sea I ice (Stuiver and others, 1981); $B R$, bedrock profile by radio echo-sounding (Calkin, 1974): PD, Packard drift; VD, Vida drift; L, possible position of melt-water lakes; dashed line, present ice profile.

to seaward, thereby tending to reduce snowfall, leading to a much retracted Schultz Glacier and possibly a non-existent Victoria Lower Glacier at this time. The dated algae suggest that, as ice-free ground was present up-stream of the present terminus of Victoria Lower Glacier at 20200 radiocarbon years $\mathrm{BP}$, ice did not spill over into Victoria Valley during the maximum of the Ross Sea I advance and that at this time Victoria Lower Glacier was considerably smaller than its present size. In its place were saline ponds and melt-water streams (Fig. 11) which, from the composition of the salts, persisted only for a geologically short interval. Subsequent withdrawal of the Ross Ice Shelf ice permitted a closer approach by the open sea and an increase in easterly snowfalls, which nourished the growth of Wilson Piedmont and Victoria Lower Glaciers. The expanding Victoria Lower Glacier, being small, would have been (and presumably still is) a dry-based glacier incapable of significant basal erosion. However, ponds of sufficiently highly concentrated salts, such as those measured in sample LVII, may depress the melting point at the glacier sole sufficiently to permit basal erosion and intermittent plucking of large blocks of lake sediments.

This scenario suggests that the Packard drift (Calkin, 1971 ) is older than the last Ross Sea event, because during at least the early part of this event the ice was well to seaward of the present margin to permit formation of the saline sediments. However, this does not preclude a correlation of the Packard drift with the Ross Sea I glaciation. It is quite conceivable that the dated algal material which formed during the Ross glaciation was overridden, but not eroded, as ice advanced to the limit delineated by the Packard drift, and has only recently been plucked from the glacier bed and transported to the glacier terminus.

The maximum Holocene incursion into Victoria Valley by Victoria Lower Glacier appears to have been only marginally greater than its present position, and the glacier is currently thinning and retreating. At present, Schultz Glacier is actively feeding ice into the system and is behaving almost as an independent glacier. The terminus of this ice extends further inland than that of area " $\mathrm{C}$ " but, although active, it does exhibit recessional features. Victoria Lower Glacier at areas "B" and "C" is a thin glacier of low activity which is currently in a state of recession.

\section{CONCLUSIONS}

Victoria Lower Glacier has been found to comprise ice from two separate sources: (A) the trunk of the adjacent Schultz Glacier which abuts against; (B) an accumulation area, feeding a tongue; (C) of discoloured ice. Wilson Piedmont Glacier does not contribute ice to this system. From field evidence and an englacial radiocarbon date, it is interpreted that over the past few thousand years Victoria Lower Glacier has either (a) advanced over salt-rich laminated sediments, about 20200 year old, to a position a little beyond the present terminus, or (b) advanced over the sediments during the latter part of the Ross Sea I glaciation and extended inland to deposit the Packard drift, the algal sediments being only recently plucked from the glacier bed to be transported to their present position in the ice of the terminus.

At present the glacier is in a state of recession, particularly pronounced towards the eastern margin where a tributary glacier has recently become disconnected. Ice " $\mathrm{C}$ " has thinned sufficiently to reduce greatly the flow rate. This has assisted in the formation of a zone of deformation between area " $\mathrm{Cl}$ and the adjacent and presumably much thicker and faster-flowing Schultz Glacier ice. Evidence from the margins indicates that the glacier is currently receding.

\section{ACKNOWLEDGEMENTS}

The work reported here was sponsored by the New Zealand Ministry of Works and Development, with field support provided by the Antarctic Division, Department of Scientific and Industrial Research, and logistic support provided by the U.S. Navy. I am grateful for the assistance given in the field by R. Dickson and T. Butler. This paper is published with the permission of the New Zealand Ministry of Works and Development.

\section{REFERENCES}

Borns, H.W., jr. 1978. Ross Sea glaciations: events in Lower Victoria Valley. Antarctic Journal of the United States, Vol. 13, No. 4, p. 43-44.

Borns, H.W., jr. 1982. Ross Sea glaciations: events in Victoria Valley. Antarctic Journal of the United States, Vol. 17 , No. 5 , p. 52-53.

Bull, C., and others. 1962. Quaternary glaciations in southern Victoria Land, Antarctica, by C. Bull, B.C. McKelvey, and P.N. Webb. Journal of Glaciology, Vol. 4, No. 31, p. $63-78$. 
Calkin, P.E. 1971. Glacial geology of the Victoria Valley system, southern Victoria Land, Antarctica. (In Crary, A.P., ed. Antarctic snow and ice studies II. Washington, DC, American Geophysical Union, p. 363-412. (Antarctic Research Series, Vol. 16.))

Calkin, P.E. 1974. Subglacial geomorphology surrounding the ice-free valleys of southern Victoria Land, Antarctica. Journal of Glaciology, Vol. 13, No. 69, p. 415-29.

Calkin, P.E. Unpublished. Geomorphology and glacial geology of the Victoria Valley system, southern Victoria Land, Antarctica. [Ph.D. thesis, Ohio State University, 1963.]

Calkin, P.E., and others. 1970. Glacial history of Wright Valley, southern Victoria Land, Antarctica, by P.E. Calkin, R.E. Behling, and C. Bull. Antarctic Journal of the United States, Vol. 5, No. 1, p. 22-27.

Chinn, T.J.H. 1980. Glacier balances in the Dry Valleys area, Victoria Land, Antarctica. [Union Géodésique et Géophysique Internationale. Association Internationale des Sciences Hydrologiques. Commission des Neiges et Glaces.] Atelier Inventaire Mondial des Glaciers. Actes de l'Atelier de Riederalp, Suisse, 17-22 septembre 1978, p. 237-47. (IAHS-AISH Publication No. 126.)

Chinn, T.J.H. 1981. Hydrology and climate of the Ross Sea area. Journal of the Royal Society of New Zealand, Vol. 11 , No. 4, p. 373-86.

Chinn, T.J.H. 1985. Structure and equilibrium of the Dry Valleys glaciers. New Zealand Antarctic Record, Vol. 6. Special Supplement, p. 73-88.

Chinn, T.J.H. In press. Accelerated ablation at a glacier ice-cliff margin. Arctic and Alpine Research.

Chinn, T.J.H., and Cumming, R.J. 1983. Hydrology and glaciology, Dry Valleys, Antarctica. Annual research report for 1978-79. Christchurch, Ministry of Works and Development. (Report No. WS 810.)

Denton, G.H. 1971. The Late Cenozoic glacial history of Antarctica. (In Turekian, K.K., ed. The Late Cenozoic glacial ages. New Haven, CT, and London, Yale University Press, p. 267-306.)

Denton, G.H., and others. 1970. Late Cenozoic glaciation in Antarctica: the record in McMurdo Sound region, by G.H. Denton, R.L. Armstrong, and M. Stuiver. Antarctic Journal of the United states, Vol. 5, No. 1, p. 15-21.
Denton, G.H., and others. 1984. Late Tertiary history of the Antarctic ice sheet: evidence from the Dry Valleys, by G.H. Denton, M.L. Prentice, D.E. Kellogg, and T.B. Kellogg. Geology, Vol. 12, p. 263-67.

Harris, C., and Bothamley, K. 1984. Englacial deltaic sediments as evidence for basal freezing and marginal shearing, Leirbreen, southern Norway. Journal of Glaciology, Vol. 30, No. 104, p. 30-34.

Hendy, C.H., and others. 1979. Late Pleistocene glacial chronology of the Taylor Valley, Antarctica, and the global climate, by C.H. Hendy, T.R. Healy, E.M. Rayner, J. Shaw, and A.T. Wilson. Quaternary Research, Vol. 11, No. 2, p. 172-84.

Holdsworth, G., and Bull, C. 1970. The flow law of cold ice: investigations on Meserve Glacier, Antarctica. [Union Géodésique et Géophysique Internationale. Association Internationale d'Hydrologie Scientifique.] [International Council of Scientific Unions. Scientific Committee on Antarctic Research. International Association of Scientific Hydrology. Commission of Snow and Ice.] International Symposium on Antarctic Glaciological Exploration (ISAGE). Hanover, New Hampshire, U.S.A., 3-7 September 1968, p. 204-16. [(Publication No. 86 [de l'Association Internationale d'Hydrologie Scientifique].)]

Mayewski, P.A. 1975. Glacial geology and late Cenozoic history of the Transantarctic Mountains, Antarctica. Ohio State University. Institute of Polar Studies. Report, No. 56.

Selby, M.J., and Wilson, A.T. 1971. Possible Tertiary age for some Antarctic cirques. Nature, Vol. 229, No. 5287, p. 623-24.

Stuiver, M., and others. 1981. History of the marine ice sheet in West Antarctica during the last glaciation: a working hypothesis, by M. Stuiver, G.H. Denton, T.J. Hughes, and J.L. Fastook. (In Denton, G.H., and Hughes, T.J., eds. The last great ice sheets. New York, etc., John Wiley and Sons, p. 319-436.)

Torii, T., and others. 1981. Geochemistry of the Dry Valley lakes, by T. Torii, S. Murata, and N. Yamagata. Journal of the Royal Society of New Zealand, Vol. 11, No. 4, p. 387-99. 